\title{
On the Veins of the Face of Macacus Cyclopsis
}

\author{
By \\ Itsuo. Nonaka \\ (Under the Supervision of Prof. Jun ichiro Satoh) \\ First Department of Anatomy, \\ Faculty of Medicine, Nagasaki University.
}

\section{Introduction}

Studies on the veins of the face of man have been done by $\mathrm{O} g$ a w a (on adult), Y a moa d a (on human fetus) and others. However, the only work that has been done on primates is that of $\mathrm{Hirota}$ (in which 6 Macaca fuscata, 2 Bengal monkey, 2 Cercopithecus aethips, 1 Simia satylus, a total of 11 animals were studied) and that of $\mathrm{K}$ a n s a k (13 Macacus rhesus), but these are somewhat insufficient to permit statistical review, discussion of the normal and abnormal forms or comparison of the results with the findings for man.

In this department, statistical studies on the anatomy of a comparatively large number of Macacus cyclopsis are being done and I have been assigned to review of the veins of the face. The results are presented in this report by which it is hoped that past works may be supplemented.

\section{Material and Method}

The material consisted of 32 adult Macacus cyclopsis (14 male, 18 female) selected from among the collection of Professor Satoh preserved in this Department. The specimen had been preserved by injection of $10 \%$ formalin solution into the femoral artery immediately after capture and strangulation. The nomenclature is used after $\mathrm{Kansaku}$.

\section{Findings and Consideration}

The veins of the face of Macacus cyclopsis are received by two major vains, i.e., V. facialis and V. retromandibularis. These two veins converge generally at a height slightly below the middle of 
the M. sternocleidomastoideus and enter the V. jugularis externa.

I. V. facialis (V. facialis anterior)

V. facialis unaccompanied by artery begins independently from $V$. angularis. It descends beneath the Pars orbitalis M. orbicularis oculi, M. levator labii superioris alaeque nasi, M. malaris and the Platysma to the Sulcus nasolabialis and then to the anterior border of the M. masseter, after which it crosses the lower edge of the mandibula to the submaxillary region. At the lower edge of the mandibula, it anastomoses with a communicating branch to the $V$. jugularis. The main trunk continues its courses backward between the mandibula and the glandula submandibularis and then enters the $V$. jugularis externa either directly or after joining with V. retromandibularis ( $V$. facialis posterior).

Union with $V$. retromandibularis most frequently is at a height slightly below the middle of the M. sternocleidomastoideus (68.8\%) followed in frequency by union at about the middle (28.1\%) while union above the middle of this muscle is rare. When compared with the findings for Macacus rhesus of $\mathrm{Kans}$ a $\mathrm{k} \mathrm{u}$, the junction is lower in Macacus cyclopsis.

With regard to the relation with $V$. jugularis externa, the $V$. facialis in Macacus cyclopsis directly or indirectly enters the $V$. jugularis externa, as described above, and this relation is exactly the same as in Chimpanzee (So n n t a g). In Simia satylus, however, this vein unites with $V$. facialis posterior and primarily enters $V$. jugularis interna ( $\mathrm{H}$ i r o t a) while in man communication between $\mathrm{V}$. facialis and V. jugularis externa is hardly ever found as the union is usually with $\mathrm{V}$. jugularis interna. That is, in man (according to $\mathrm{Mochizuki}$ ) the $\mathrm{V}$. facialis most frequently directly or indirectly enters the $V$. jugularis interna $(54.1 \%)$ and enters the $V$. jugularis externa in few cases $(31.6 \%)$. Also, in human fetus also (according to $\mathrm{Yamada}$ ) the frequency of entry into the $\mathrm{V}$. jugularis interna $(50.0 \%)$.

Tributaries of $V$. facialis are as follows. (fig. 1, 2)

1) Vv. Supratrochleares (Vv. frontales)

These veins, which drain the subcutaneous venous network of the forehead descends toward the root of the nose to become the V. angularis. It often accompanies by an artery. Its course has been classified into 3 types for human fetus by $\mathrm{Y}$ a $\mathrm{m}$ a d a while $\mathrm{Ka} \mathrm{n} \mathrm{sa} \mathrm{k} \mathrm{u}$ also has classified the findings for Macacus rhesus in a similar fashion. I have classified the findings for Macacus cyclopsis into the following 


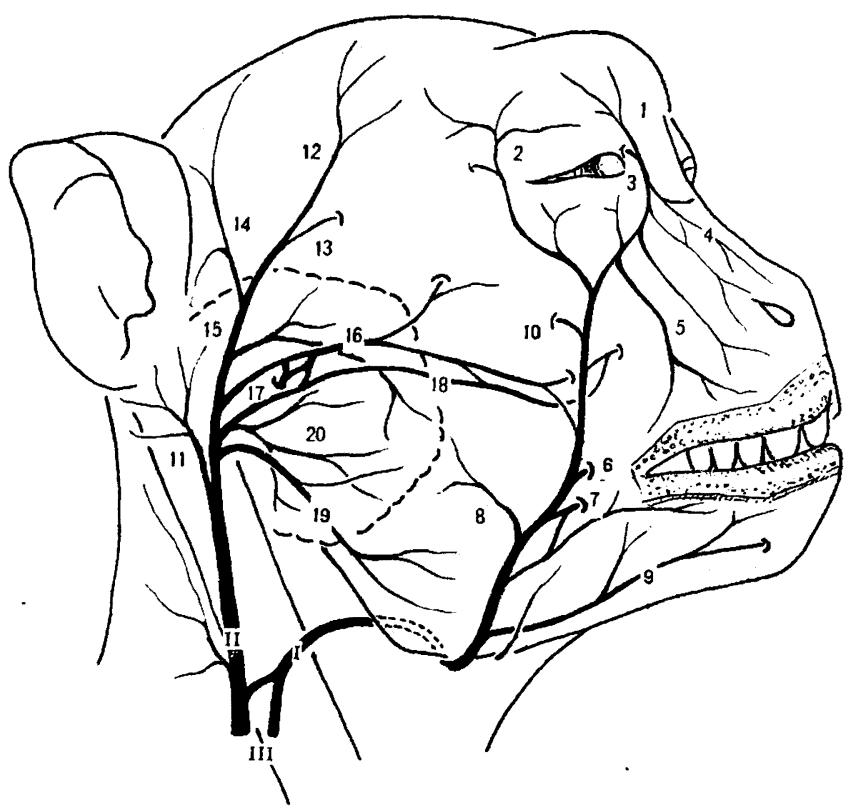

Fig. 1. 1. Vv. supratrochleares (Vv. frontales) 2. V. supraorbitalis 3. V. angularis 4. Vv. nasales externae 5 . V. labialis superior 6. V. faciei profunda (radix prof. v. fac. ant.) 7. V. buccalis 8. Vv. massetericae anterior 9. Vv. labiales inferiores 10. R. comm. v. temp. med. 11. V. auriculooccipitalis 12. Vv. temporales superficiales 13. V. temporalis media 14. V. aurricularis anterior 15. V. temporalis communis 16. V. transversa faciei 17. Vv. articulares mandibulae 18. Vv. comitantes ductus parotidei 19. Vv. massetericae posterior 20. Vv. parotideae I. V. facialis (V. facialis anterior) II. V. retromandibularis (V. facialis post.) III. V. jugularis externa

4 types (table 1, fig. 3).

Type I: There is one vein on each side which follow a symmetrical course. This is the most frequent type (87.5\%). It is possible to divide this type into 4 subtypes (fig. 4).

(a) Cases with a large communicating branch at the root of the nose $(18.8 \%)$

(b) Cases with another large communicating branch at the upper forhead or between the eye brows in addition to a large communicating branch at the root of the nose $(3.1 \%)$

(c) Cases with no communicating branch either at the root of the nose or between the eye brows (56.3\%) 
(d) Cases with a venous network at the forehead with constitute a communicating branch in addition to two $\mathrm{Vv}$. supratrochleares $(9.4 \%)$.

Type II: There is one V. supratrochlearis which bifurcates at between the eye brows. There was only one case of this type $(3.1 \%)$.

Type III: This is a condition which might be called a mixture of types I and II $(6.3 \%)$.

Type IV: The main trunk of Vv. supratrochleares is absent on the forehead with a venous network in its place $(3.1 \%)$.

The frequency of the above types were compared with that for human fetus ( $\mathrm{Yamada}$ ) and Macacus rhesus (Kansaku). In

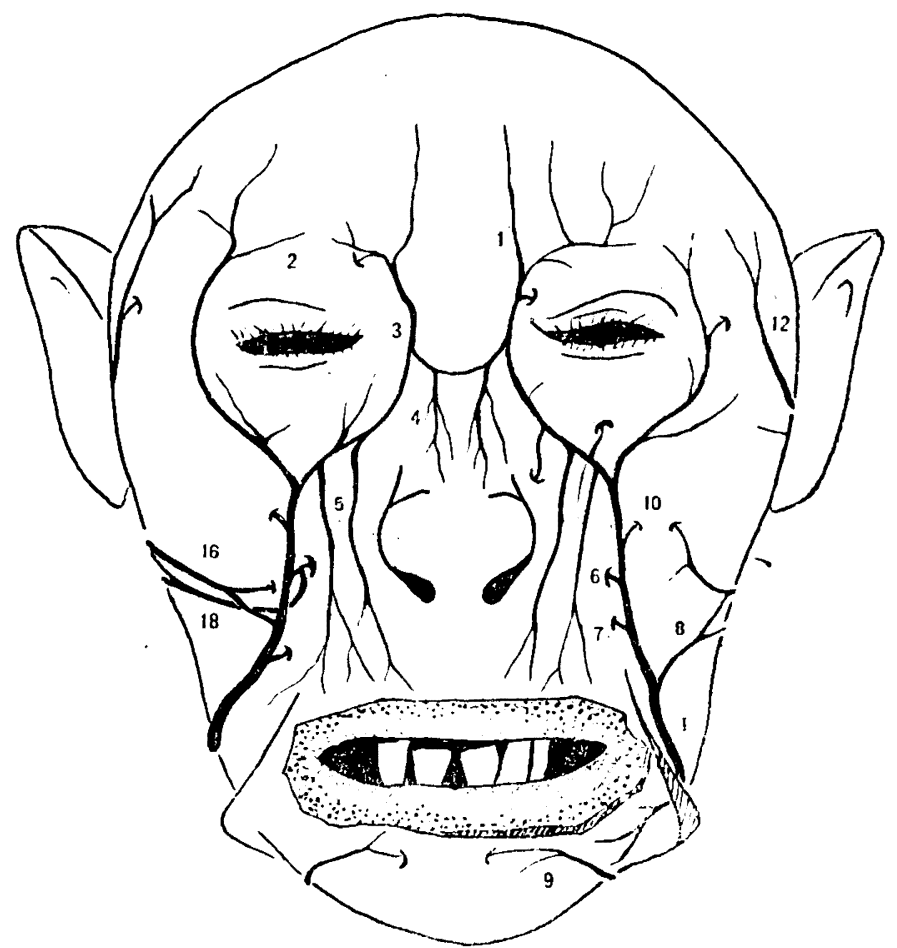

Fig. 2. 1. Vv. supratrochleares (Vv. frontales) 2. V. supraorbitalis 3. V. angularis 4. Vv. nasales externae 5. Vv. labiales superiores 6. V. faciei profunda (radix prof. v. fac. ant.) 7. V. bucclis 8. Vv. massetericae anterior 9. Vv. labiales inferiores 10. R. comm. v. temp. med. 12. Vv. temporales superficiales 16. V. transversa faciei 18. Vv. comitantes ductus parotidei I. V. facialis (V. facialis anterior) 
Table 1

\begin{tabular}{|c|c|c|c|}
\hline Mype & $\begin{array}{l}\text { Macacus cyclopsis } \\
\text { (Nonaka) }\end{array}$ & $\begin{array}{l}\text { Macacus rhesus } \\
\text { (Kansaku) }\end{array}$ & $\begin{array}{c}\text { Human fetus } \\
\text { (Japanese) } \\
\text { (Yamada) }\end{array}$ \\
\hline I & $87.5 \%$ & $61.5 \%$ & $32.5 \%$ \\
\hline II & $3.1 \%$ & $23.0 \%$ & $60.0 \%$ \\
\hline III & $6.3 \%$ & 0 & 0 \\
\hline IV & $3.1 \%$ & $15.3 \%$ & $7.5 \%$ \\
\hline
\end{tabular}

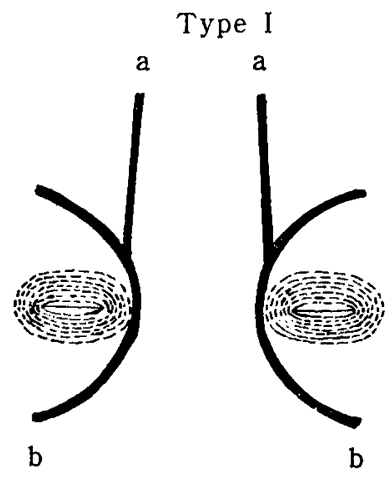

Type III

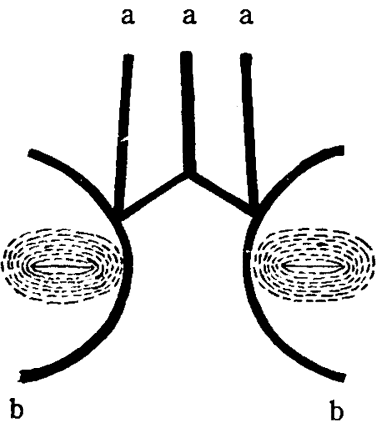

Type II

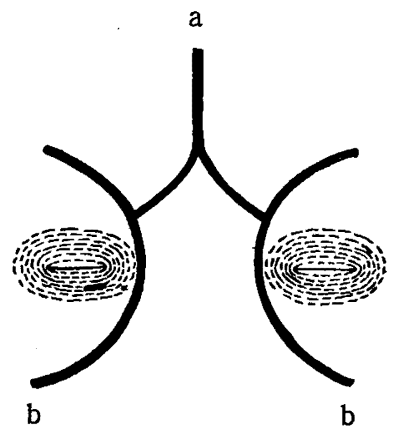

Type IV

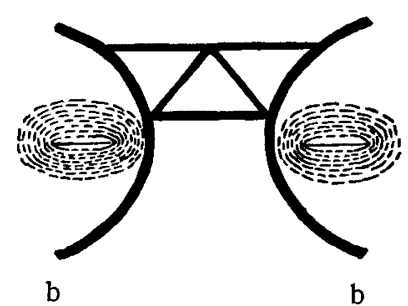

Fig. 3. a......Vv. supratrochleares (Vv. frontales) b...... V. angularis

human fetus, type II in which there is one V. supratrochleares which divides into two branches at between the eye brows is the usual form. Contrarily, this type is rare in monkey and type $I$ in which two veins, one on each side, follow a symmetrical course is the most frequent. The frequency of these types show the findings for Macacus cyclopsis are more similar to the findings for Macacus rhesus than 


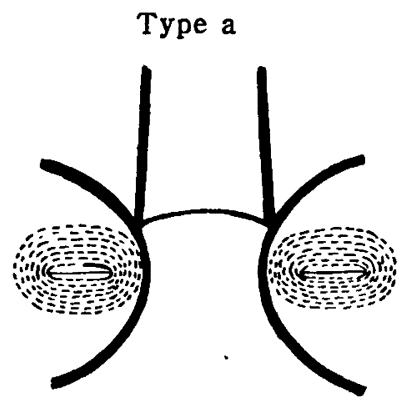

Type c
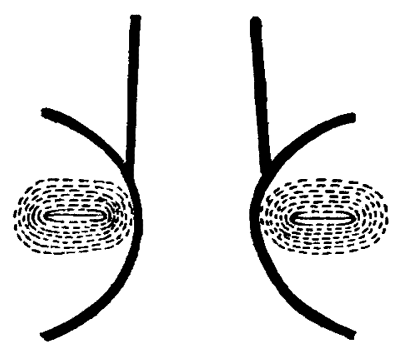

Type b

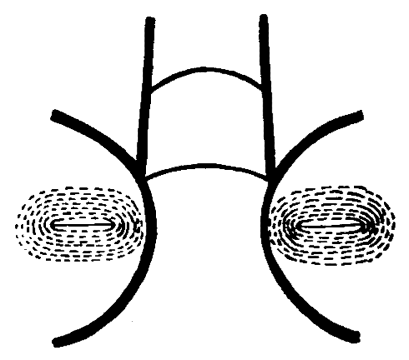

Type d

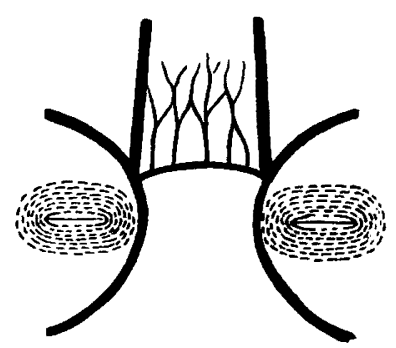

Fig. 4

that of human fetus.

2) V. supraorbitalis

This vein, accompanied by an artery of the same name, runs transversely along the upper margin of the orbit. The medial end is continuous with $V$. supratrochleares and $V$. angularis while the lateral end continues with V. temporalis media. This vein was absent in none of the cases.

3) V. angularis

This vein was present in all cases. It receives the Vv. palpebrae superior and inferior, Vv. nasales externae, etc. and becomes the V. facialis.

4) Vv. nasales externae

The many small veins which begin in the venous network on the bridge of the nose anastomose with each other as they ascend to form the $\mathrm{Vv}$. nasales externae which enter the $\mathrm{V}$. angularis. It is said that in Macacus rhesus there usually are four vessels, but in Macacus cyclopsis two was the most frequent number (53.1\%).

5) V. labialis superior 
This vein commences in the venous network in the upper lip and consists of one or two vessels. It ascends obliquely beneath the M. malaris, M. levator labii superioris and M. levator labii superioris alaeque nasi to enter the $\mathrm{V}$. facialis. It is not accompanied by an artery. In man ( $\mathrm{O} \mathrm{g} \mathrm{a} \mathrm{w} \mathrm{a}, 48.7 \%)$ and Macacus rhesus (53.8\%) most frequently there is one vessel, but in Macacus cyclopsis there more frequently were two vessels $(70.3 \%)$ followed in frequency by one vessel $(14.1 \%)$.

6) V. faciei profunda (Radix prof. v. fac. ant.)

This vein begins from the Plexus pterygoideus. The veins unite to form one vessel which passes forward on the infratemporal surface of the maxilla to the anterior border of the M. masseter and joins the $V$. facialis near the orifice of ductus parotideus. The junction of this vein with V. facialis is immediately below (92.2\%) or immediately above $(6.3 \%)$ the point where the ductus parotideus and V. facialis cross. This is generally consistent with the finding of $\mathrm{H}$ i rot a but in Macacus rhesus the opening is said to be immediately above the point of crossing. This vein was absent in some cases but the frequency of such cases is very low compared with adult man (O g a wa $19.5 \%)$ and Macacus rhesus $(7.7 \%)$.

7) V. buccalis

This vein commences from the Plexus pterygoidus and emerges on the exterior surface of $\mathrm{M}$. buccinator to unite with the $\mathrm{V}$. facialis at the height of the angle of the mouth. This vein was absent in rare cases $(1.6 \%)$, but the frequency of absence is much lower than that in adult $(31.7 \%)$ or Macacus rhesus $(26.9 \%)$.

8) Vv. massetericae anterior

These veins begin on the lower lateral surface of the M. masseter and enter the $\mathrm{V}$. facialis at the lower anterior margin of the M. masseter. This vein was present in all cases.

9) Vv. labiales inferiores

These veins commence on the lower lip and pass obliquely downward beneath the Platysma. At the base of the mandibula it receives the V. submentalis and enters the V. facialis. It frequently is accompanied by an artery and is present in all cases. In rare cases, anastomosis with V. labialis superior is noted at the angle of the mouth.

10) R. comm. v. temp. med.

This branch which communicates with $\mathrm{V}$. facialis at above the mouth of the Ductus parotideus, enters the M. temporalis at the 
anterior tip of the zygomatic arch and unites with the V.temporalis media. It is present in almost all cases being unrecognized in only a small number of cases $(3.1 \%)$.

In addition, $\mathrm{Vv}$. palpebrales superiores, $\mathrm{Vv}$. palpebrales inferiores and $\mathrm{V}$. submentalis also join the $\mathrm{V}$. facialis but due to convenience of material, these veins were not studied.

II. V. retromandibularis (V. facialis post.)

The V. retromandibularis, unaccompanied by an artery, descends in the substance of the parotid gland to the lower edge of the parotid gland. In the majority of cases it enters the $V$. jugularis externa directly or after union with V. facialis at the height slightly below the middle of the lateral side of the M. sternocleidomastoideus.

The V. retromandibularis receives the following veins (fig. 1, 2).

11) V. auriculooccipitalis

The $V$. retroauricularis and $V$. occipitalis descend into the lower portion of the parotid gland where they unite. After a short distance this vein enters the V. retromandibularis. First, it is accompanied by an artery but it later separates from the artery.

12) Vv. temporales superficiales

These veins arise in the network of small veins at the parietal region. From this network emarge branches which unite to form a single vessel near the upper part of the attachment of the auricle. This vein descends in front of the auricle and joins with the $V$. temporalis media on the lateral surface of the posterior tip of the zygomatic arch to become the $V$. temporalis communis.

13) V. temporalis media

This vein begins in the superficial portion of the temporalis. The veins pass backward to the upper border of the posterior tip of the zygomatic arch where they become a single vessel which emerges into the subcutaneous region and unite with the Vv. temporales superficiales.

14) V. auricularis anterior

This vein begins at the upper anterior edge of the auricle and enters the V. temporalis communis at the lower border of the posterior tip of the zygomatic arch. This vein accompanies by an artery.

15) V. temporalis communis

This vein is formed at the lower border of the posterior tip of the zygomatic arch and runs downward into the parotid gland. After joining with V. transversa faciei, Vv. articulares mandibulae and V. parotideae, it enters the V. retromandibularis. 
16) V. transversa faciei

This vein commences over the M. masseter below and in front of the zygomatic arch. The veins form one to three vessels which run into the parotid gland accompanied by an artery. It then becomes a single vessel and most frequently enters the so-called "Conf. v. preaur. (Mochizuki)" (98.4\%). Entry into the Vv. articulares mandibulae as noted by $\mathrm{K}$ a $\mathrm{ns}$ a $\mathrm{k} \mathrm{u}$ in Macacus rhesus (26.9\%) was seen in only one case $(1.6 \%)$ in Macacus cyclopsis.

This vein anastomoses with the V. faciei profunda, R. comm. V. temp. med., V. comitantes ductus parotidei, etc. on the mouth (anterior) side. In particular, anastomoses with V. facialis (28.6\%) and v. comitantes ductus parotidei (53.8\%) are most frequent.

17) Vv. articulares mandibulae

These veins árise in the Plexus pterygoideus and emerge on the external side of the mandibular joint. After penetrating the $M$. masseter it anastomoses with V. transversa faciei. Entry into the $V$. temporalis communis which is said to occur in Macacus rhesus $(11.5 \%)$ is not found in Macacus cyclopsis.

18) Vv. comitantes ductus parotidei

This vein begins in the Plexus parotideae, runs backward along the Ductus parotidae and separates into one to five vessels which primarily enter the $\mathrm{V}$. temporalis communis (98.4\%). There are cases in which a branch is seen anastomosing with $V$. auriculooccipitalis, Vv. temporales superficiales or V. retromandibularis. Anteriorly, it becomes one or two vessels and anastomoses with V. facialis, V. faciei profunda, V. temporalis media or V. buccalis.

19) Vv. massetericae posterior

This vein begins behind the M. masseter and consists of one or two vessels which enter the $V$. temporalis communis. This vein is present in all cases.

20) Vv. parotideae

These veins commence in the parotid gland and three or four vessels are always noted. They enter the V. retromandibularis.

Furthermore, in the parotid gland, as pointed out by $\mathrm{H}$ irota and $\mathrm{Kansa \textrm {k }}$, V. transversa faciei, Vv. articulares mandibulae, V. comitantes ductus parotidei, Vv. massetericae posterior, etc. anastomose with each other and form singular or multiple loops or rings.

Also, the venous plexus seen in man on the preauricular region (conf. v. praeaur., M o c hiz u ki) is found in Macacus cyclopsis, too. However, the V. facialis does not contribute to the formation of this 
plexus in any of the cases (fig. 5).

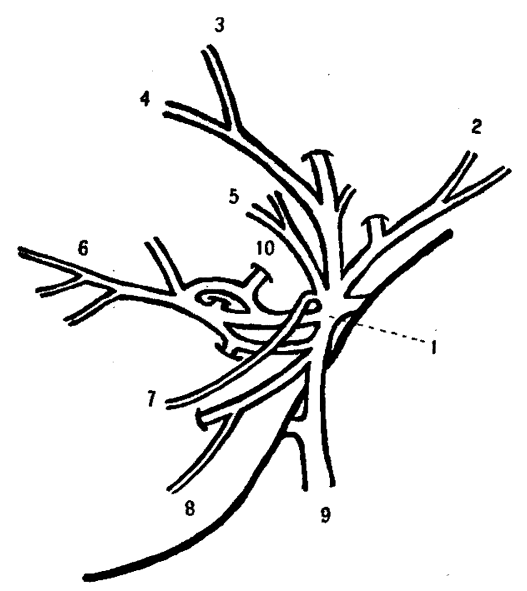

(No. $93, \%$ )

Fig. 5. 1. V.temporalis communis 2. V. auricularis anterior 3. Vv. temporales superficiales 4. V. temporalis media 5. Vv. parotideae 6. V.transversa faciei 7. Vv. comitantes ductus parotidei 8. Vv. massetericae posterior 9. V. retromandibularis (V. facialis post.) 10. Vv. articulares mandibulae

III. The relation between V. facialis, V. retromandibularis and V. jugularis externa (table 2, fig. 6, 7)

Table 2

\begin{tabular}{|c|c|c|c|c|}
\hline Side Type & I & II & III & IV \\
\hline Right & 17 & 9 & 5 & 1 \\
\hline Left & 18 & 12 & 2 & 0 \\
\hline Total & 35 & 21 & 7 & 1 \\
\hline$\%$ & 54.7 & 32.8 & 10.9 & 1.6 \\
\hline
\end{tabular}

As mentioned above, the $V$. facialis in monkey enters the V. jugularis externa but in man communication with the $\mathrm{V}$. jugularis externa is lost and it enters the $V$. jugnlaris interna in the majority of cases. I have reviewed the findings in Macacus cyclopsis for these two veins along with the $\mathrm{V}$. retromandibularis with regard to their state of junction. Their condition may be classified into the following four types. 


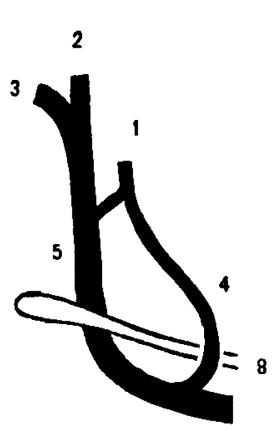

I

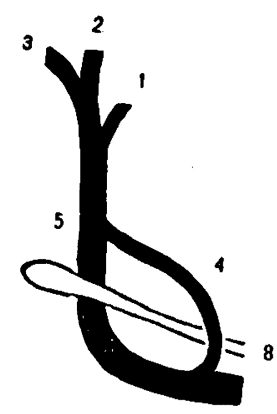

II

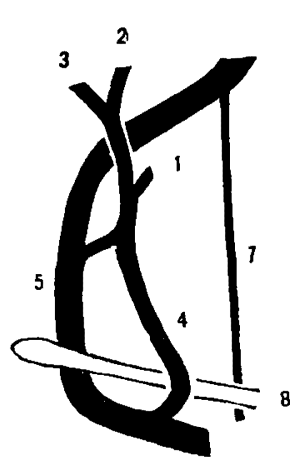

III

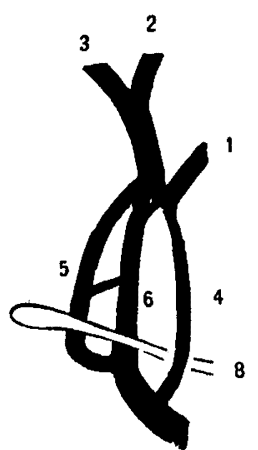

IV

Fig. 6. 1. V. facialis (V. facialis anterior) 2. V. retromandibularis (V. facialis post.) 3. V. auriculooccipitalis 4. V. jugularis externa (ant.) 5. V. jugularis externa (post.) 6. V. jugularis externa (med.) 7. V. angularis 8. Clavicula

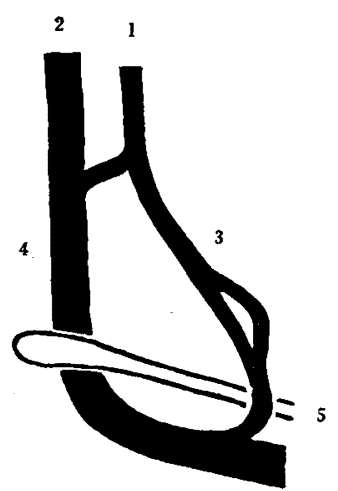

Fig. 7. 1. V. facialis (V. facialis anterior) 2. V. retromandibularis (V. facialis post.) 3. V. jugularis externa (anterior) 4. V. jugularis externa (posterior) 5. Clavicula

Type I: V. facialis and V. retromandibularis unite on the external side of the M. sternocleidomastoideus at the height of about one third from the clavicle or at about the center of the M. sternocleidomastoideus or slightly higher and immediately separate into an anterior branch and a posterior branch that form a large external jugular venous loop (54.7\%).

Type II; V. facialis and V. retromandibularis unite behind the mandibular angle to form a single $V$. jugularis externa which passes downward and soon separates into an anterior branch and a posterior branch that form a large external jugular venous loop (32.8\%). The anterior and posterior branches of these loops join at behind the 
sternal extremity of the clavicle, pass obliquely medially downward and, together with the V. subclavia and V. jugularis interna, form the V. brachiocephalica.

Type III: The course of the anterior branch of the V.jugularis externa is the same as the former two but the posterior branch further separates into upper and lower branches. The lower branch follows the same course as the previous two types but the upper branch passes obliquely upward on the internal side of the M. sternocleidomastoideus and joins with the V. jugularis interna. In these cases the V. jugularis interna is extremely small (10.9\%).

Type IV: The V. jugularis externa separates into anterior, medial and posterior branches. Of these, the medial branches is the largest and the anterior and posterior branches generally are of equal size. Furthermore, the anterior and posterior branches follow the same course as the abovementioned types but the medial branch after separating from the anterior branch passes vertically downwards from the middle of the external side of M. sternocleidomastoideus and joins with the posterior branch on the internal side of the clavicle $(1.6 \%)$.

In such a classification, type $I$ is the most frequent $(54.7 \%)$ in Macacus cyclopsis followed by type II $(32.8 \%)$. In the report by $\mathrm{H}$ i rot a on monkey, there is no record of type III or IV but cases which correspond to my type I appear to be the most numerous.

Among the above classification types, there are cases in which the anterior or posterior branches of the V. jugularis externa form additional smaller loops. Such a condition was noted in the anterior branch in three cases and in the posterior branch in three cases (fig. 7). When the anterior and posterior branches are compared, the posterior branch was larger in the majority of cases (85.9\%). They were equal in size $(12.5 \%)$ and the posterior branch was smaller $(1.6 \%)$.

\section{Summary}

Dissection of 32 bodies of Macacus cyclopsis was done and the following were obtained for the facial veins.

I. The veins of the face are received by V. facialis and V. retromandibularis.

II. V. facialis passes beneath the pars orbitalis M. orbitalis oculi, M. levator labii superioris alaeque nase, M. malaris and Platysma and runs toward the mandibular angle. It then courses backward between the mandibula and the glandula submandibularis and in most 
cases enters the V. jugularis externa either directly of after joining with the $V$. retromandibularis at the height of slightly below the middle of the external side of $M$. sternocleidomastoideus. The veins received by $V$. facialis are as follows.

1. Most usually there is one V. supratrochlearis on each side which follow a symmetrical course (87.5\%), but there are cases in which there is a single vessel which bifurcates at the root of the nose or cases in which both of the preceeding two forms are present simultaneously while in other cases it is absent.

2. V. supraorbitalis is always present.

3. V. angularis is always present.

4. Vv. nasales externae arise in the venous network on the bridge of the nose. The veins anastomose and form several vessels, two in most cases (53.1\%), which run upward to enter the V. angularis.

5. V. labialis superior which is unaccompanied by an artery consists of two vessels in most cases (70.3\%).

6. V. faciei profunda was noted in almost all cases $(98.4 \%)$ and opens into the $\mathrm{V}$. facialis generally immediately below the point of crossing of the Ductus parotideus and V. facialis (92.2\%).

7. V. buccalis was noted in the greater majority of cases $(98.4 \%)$.

8. Vv. massetericae anterior are always present.

9. Vv. labiales inferiores were always present. In very rare cases, they anastomosed with the V. labialis superior.

10. R. comm. v. temp. med. was present in almost all cases (96.8\%). There were cases in which its presence could not be recognized.

III. V. retromandibularis descends in the substance of the parotid gland to the lower edge of the parotid gland. It enters the V. jugularis externa either directly or after joining with the $\mathrm{V}$. facialis at slightly below the middle of the M. sternocleidomastoideus.

Veins received by the $V$. retromandibularis are as follows:

1. V. auriculoccipitalis is always found and in the majority of cases it enters the $V$. retromandibularis in the lower portion of the parotid gland.

2. Vv. temporales superficiales become a single vessel and unite with $\mathrm{V}$. temporalis media after which it enters the $\mathrm{V}$. temporalis communis. cases.

3. V. temporalis media is a single vessel and is present in all

4. V. auricularis anterior is always present.

5. V. temporalis communis is always present. 
6. V. transversa faciei most frequently enters, so-called, the Conf. v. preaur. (98.4\%) and anteriorly usually anastomoses with V. comitantes ductus parotidei $(53.8 \%)$ or V. facialis $(28.6 \%)$.

7. Vv. articulares mandibulae are always present and enter $V$. transversa faciei.

8. Vv. comitantes ductus parotidei run backward along the parotid duct and chiefly join $\mathrm{V}$. temporalis communis (98.4\%). Anteriorly, they primarily anastomose with $\mathrm{V}$. facialis (53.3\%).

9. Vv. massetericae posterior consist of one or two vessels and are present in all cases.

10. Vv. parotideae consist of 3 or 4 vessels and are never absent.

11. A vein corresponding to the Conf. v. preaur. in man (of $\mathrm{M} \mathrm{oc} \mathrm{h} \mathrm{i} \mathrm{z} \mathrm{u} \mathrm{k} \mathrm{i)} \mathrm{is} \mathrm{recognized} \mathrm{but} \mathrm{in} \mathrm{Macacns} \mathrm{cyclopsis} \mathrm{V.} \mathrm{facialis} \mathrm{does}$ not contribute to its formation.

IV. The state of union between V. facialis, V. retromandibularis and V. jugularis externa may be classified into 4 types but in the greatest number of cases $\mathrm{V}$. facialis and $\mathrm{V}$. retromandibularis unite and in addition form a large external jugular venous loop (46.9\%).

Also, in a small number of cases the anterior and posterior branches of the external jugular venous loop formed further small loops.

\section{Literature}

1) G. Hieda: On the subcutaneous veins of the neck region in Japanese. (Japanese) Igaku Kenkyu Vol. 3, No. 9, 1929.

2) K. H irota: On the vein-systems of Mammal. (Japanese) Kyoto Igk. Z. Vol. 24, No. 3, 1927.

3) T. Ka n s k u: On the veins of the eye-cavity in Pithecus rheuses. (Japanese) Tokyo Igkk. Z. Vol. 52, No. 4, 1938.

4) S. Mochizuki: Studies on the veins. (Japanese) Keio Igk. Z. Vol. 5, No. $1,1952$.

5) M. Og aw a: The facial veins in Japanese. (Japanese) Nippon Geka Hookan Vol. 10, No. 6, 1933.

6) C.F. Son ntag: The anatomy, physiology, and pathology of the Chimpazee. Proc. Zool. Soc. London, 1923.

7) C.F.S on tag: The morphology and evolution of the apes and man. London, 1924.

8) Y. Tada: Studies on the facial veins in Japanese. (Japanese) Nippon Kohku Z. Vol. 1, No. 3, 1952.

9) S. Y a mada: On the vein-systems of neck, face cranium and thymus gland in Japanese fetus. (Japanese) Kaibo Z. Vol. 8, No. 1, 1935. 